\title{
Immunohistochemical Localization of Estrogen Receptor in the Embryonic Gonad of Male Quail Embryo During Gonadal Differentiation
}

\author{
Localización Inmunohistoquímica del Receptor de Estrógeno en la Gónada Embrionaria \\ en el Embrión de Codorniz Macho Durante la Diferenciación Gonadal
}

Sittipon Intarapat; Achariya Sailasuta** \& Orawan Satayalai***

INTARAPAT, S.; SAILASUTA, A. \& SATAYALAI, O. Immunohistochemical localization of estrogen receptor in the embryonic gonad of male quail embryo during gonadal differentiation. Int. J. Morphol., 34(2):575-579, 2016.

SUMMARY: In birds, male embryo the gonads develop bilateral testes, in which both left and right sides produce functional spermatozoa, whereas female embryo, only the left gonad develops into a functional ovary. Estrogen plays a key role in avian sex determination in both sexes by binding to the estrogen receptor (ER). Surprisingly, chicken estrogen receptor (cER) mRNA is expressed in both sexes; moreover; its expression is only expressed in the left male gonad. The present study aimed to localize ER protein in the left gonad of male quail embryo using immunohistochemistry. The 8-day-old male quail embryos whose embryonic sex distinguished by gonadal morphology were studied. Histology of the left male gonad displayed thin cortex containing 1 to 2 layers of the germinal epithelium, while testicular cords were observed in the medulla. ER-immunoreactive cells were only found in the germinal epithelium but not in the medulla. Localization of ER was detected in the nucleus and cytoplasm of the germinal epithelial cells. The number of ER-immunoreactive cells counted in upper, lateral, and lower regions of the germinal epithelium was $18.20 \pm 1.892,17.60 \pm 1.887$, and $16.20 \pm 1.290$, respectively. This study shows the first evidence for expression of ER protein in the left male gonad of the avian embryo, indicating that ER plays a role in avian gonadal sex differentiation.

KEY WORDS: Estrogen receptor; Embryonic gonad; Gonadal differentiation; Quail embryo.

\section{INTRODUCTION}

In avians, male homogametic sex (ZZ), the gonads develop symmetrically, whereas female heterogametic sex (ZW), the gonads develop asymmetrically- only the left side develops into a functional ovary (Romanoff, 1960). Estrogen was reported to play a role in sex determination and gonadal differentiation in birds (Smith \& Sinclair, 2004). Strikingly, estrogen and its receptor are asymmetrically expressed in avian embryonic gonads during sexual differentiation (Andrews et al., 1997; Nakabayashi et al., 1998). Asymmetric expression of estrogen and its receptor in chicken embryonic gonads is related to left-right gonadal asymmetry in birds (Intarapat \& Stern, 2014).

Previous study has reported that distribution of estrogen target cells is restricted only in the left gonad of chicken embryo in both sexes (Gasc, 1980). Interestingly, the left gonad also had more cER expression than the right gonad in both sexes, as shown by whole-mount in situ hybridization (Andrews et al.; Nakabayashi et al.). Localization of ER protein was only studied in female embryonic gonads (Andrews et al.). Moreover, no evidence to show that ER protein is expressed in male embryonic gonad of chicken embryos at the sexually differentiated stage. This study aimed to investigate whether the left male gonad of quail embryo expresses ER protein during gonadal differentiation by immunohistochemistry.

\section{MATERIAL AND METHOD}

Embryo collection and histological examination. Japanese quail (Coturnix japonica) eggs were obtained from the Department of Animal Science, Kasetsart University, Thailand. Quail eggs were incubated at $37.5{ }^{\circ} \mathrm{C}$ in the incubator with humidity for 8 days (the stage that embryonic

\footnotetext{
* Department of Anatomy, Faculty of Science, Mahidol University, Bangkok, Thailand.

** Department of Pathology, Faculty of Veterinary Science, Chulalongkorn University, Bangkok, Thailand.

**** Department of Biology, Faculty of Science, Chulalongkorn University, Bangkok, Thailand.
} 
sex can be distinguished by gonadal morphology). The 8day-old male embryonic gonads with the mesonephroi were dissected under SZ-PT stereomicroscope (Olympus, Japan). The dissected gonads were fixed with Bouin's fluid for $24 \mathrm{~h}$ (for histological examination) and $4 \%$ paraformaldehyde for $16 \mathrm{~h}$ (for immunohistochemistry). The fixed gonads were rinsed in absolute ethanol then dehydrated in graded series of ethanol, cleared in xylene, and embedded in Paraplast (Sherwood Medical Company, USA.). Paraffin sections were cut at 6 and $5 \mu \mathrm{m}$ for histological and immunohistochemical examinations, respectively. The sections were then stained with haematoxylin and eosin $(\mathrm{H} \& \mathrm{E})$ and immunohistochemistry for estrogen receptor (ER). For immunohistochemistry, the sections were placed on the slide coated with $0.01 \%$ poly-Llysine (Sigma Chemical Company, USA).

ER-immunohistochemistry. The sections were deparaffinized and rehydrated in graded series of ethanol concentrations. Immunohistochemistry procedures were performed according to the manufacturer's protocols. The antigen retrieval method was performed by microwaving the slides twice (10 min, $800 \mathrm{~W}$ in $10 \mathrm{mM}$ of citrate buffer, $\mathrm{pH}$ 6.0), and then washed in $0.05 \mathrm{M}$ PBS, pH 7.4. Sections were added with $3 \% \mathrm{H}_{2} \mathrm{O}_{2}$ /methanol for 10 min to block endogenous peroxidase activity and then with $0.5 \%$ Triton $\mathrm{X}-100$, incubated in humidified chamber for $20 \mathrm{~min}$ at room temperature. The sections were added with blocking solution containing $1 \%$ normal goat serum in PBS provided in the immunoperoxidase secondary detection kit (Chemicon International, USA) for blocking non-specific binding for 5 $\mathrm{min}$. The sections were rinsed with $1 \mathrm{X}$ rinse buffer and then incubated with primary antibody, mouse anti-estrogen receptor monoclonal antibody (1:100, Chemicon International Temecula, Canada) for $24 \mathrm{~h}$ at $4{ }^{\circ} \mathrm{C}$, then with secondary antibody, biotinylated goat anti-mouse IgG for ER (Chemical International, USA) for $10 \mathrm{~min}$. The sections were rinsed with $1 \mathrm{X}$ rinse buffer, and a solution of the biotin-streptavidin peroxidase complex was added following the manufacturer's protocols. Tissues were revealed using diaminobenzidinehydrogen peroxide medium $\left(\mathrm{DAB}-\mathrm{H}_{2} \mathrm{O}_{2}\right)$ for $10 \mathrm{~min}$ in humidified chamber at room temperature and then washed with rinse buffer. The sections were counterstained with Mayer's haematoxylin. Control sections were incubated with the incubation medium omitting the primary antibody. Finally, the sections were dehydrated, mounted and photographed by PM-10 M3 camera (Olympus, Japan).

Analysis of ER-immunoreactive cells. To quantify the number of ER in male embryonic gonads, immunoreactive cells localized in the germinal epithelium were counted circumferentially (upper, lateral, lower regions) of entire gonadal sections at 200X magnification starting from the first section to the tenth section in accordance with counting method described in the previous study (Intarapat \& Satayalai, 2014). To avoid counting the same cells, one in three sections was counted until the last section of the embryonic gonad was reached (Intarapat \& Satayalai). The quantitative data was analyzed using SPSS and presented as mean + SEM.

\section{RESULTS}

In this study, embryonic development of Japanese quail was staged according to Padgett \& Ivey (1960). Embryonic gonads of 8-day-old male quail embryo, stage Q35 (P\&I) was equivalent to chicken embryo stage 34 Hamburger and Hamilton (H\&H) (Hamburger \& Hamilton, 1951). Male embryonic gonads can be distinguished from female embryonic gonads by gonadal morphology since day 8 of incubation. Gonadal anatomy of male embryo exhibited symmetrical gonads developing on the mesonephroi (Fig. 1), whereas female embryos displayed asymmetrical gonads (data not shown). In the present study, histological structures of the left gonad of male embryo were studied. Thin germinal epithelium containing 1-2 layers of squamous epithelial cells was observed in the cortex, while testicular cords, the future seminiferous tubules, were noticed in the medulla (Fig. 2). The connecting stalk was observed at the hilum region where embryonic gonad attached to the mesonephros (Fig. 2).

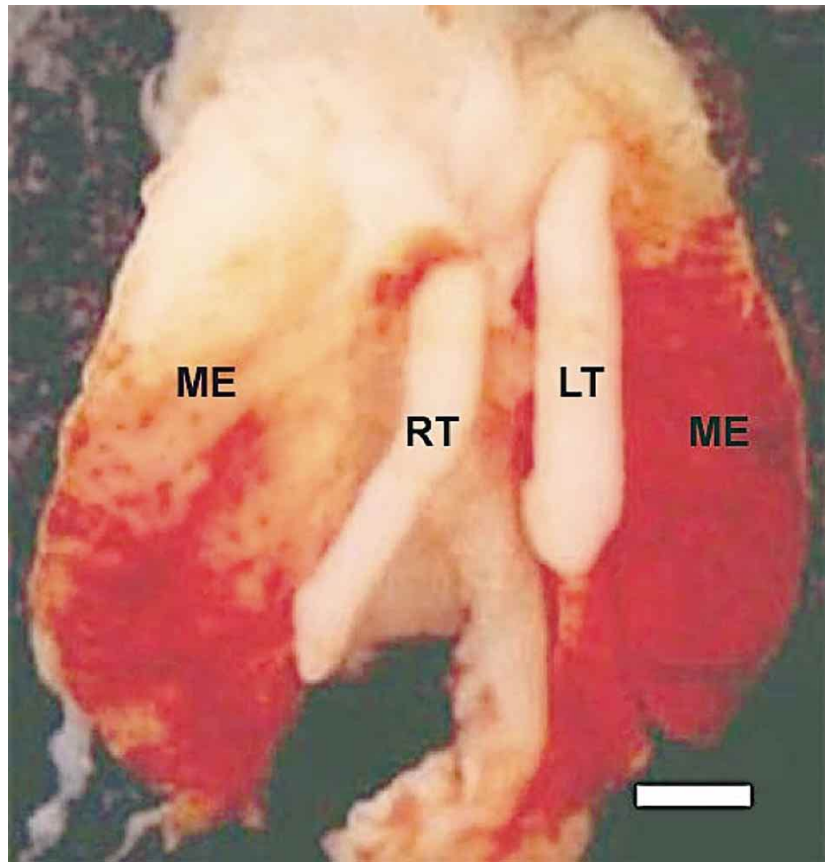

Fig. 1. Embryonic gonads of 8-day-old male quail embryo during gonadal differentiation (at sexually differentiated stage) showing symmetrical (bilateral) gonads. Note: the left testis (LT) and the right testis (RT) are located at the medioventral part of the mesonephros (ME) (Scale bar: $0.5 \mathrm{~mm}$ ). 


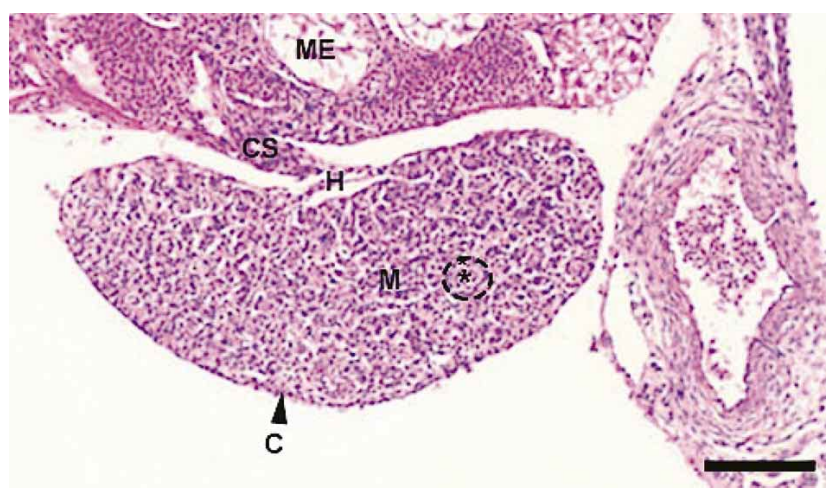

Fig. 2. Histological characters of the left male gonad of 8-day-old quail embryo. Note: thin cortex (C, arrowhead) containing 1-2 layers squamous epithelial cells and testicular cord (asterisk) in the medulla (M). The gonad connected with the mesonephros (ME) via the connecting stalk (CS) at the hilum (H). (H\&E 100X) (Scale bar: $100 \mu \mathrm{m})$.
In this study, ER-immunoreactive cells were identified as a target of estrogen during gonadal differentiation. ER-immnoreactive cells were found specifically in the germinal epithelium of the cortex but not in the medulla (Fig. 3A). Localization of ER in the nucleus and cytoplasm of germinal epithelial cells was found (Fig. 3C). Quantitative data showed that the number of ERimmunoreactive cells localized in the upper, lateral, and lower regions of gonadal sections was $18.20 \pm 1.892$, $17.60 \pm 1.887$ and $16.20 \pm 1.290$, respectively (Table I). No ER-immunoreactive cells in the negative control (Figs. 3B and 3D) as well as the right male gonad (data not shown).

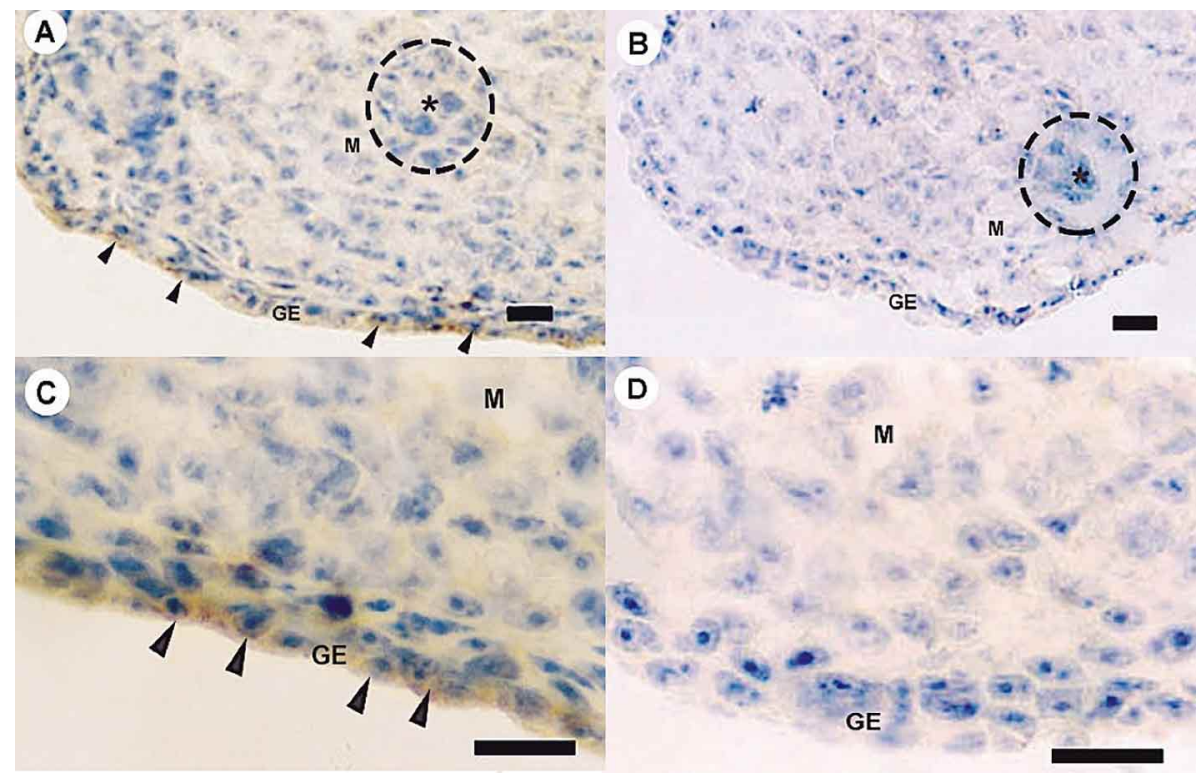

Fig. 3. Immunohistochemical staining for estrogen receptor (ER) in the left male gonad of 8-day-old quail embryo. (A) ER-immunoreactive cells (arrowheads) in the germinal epithelium (GE). (C) Localization of ER was found in the nucleus and cytoplasm of the germinal epithelial cells (arrowheads). (B, D) No reaction in the negative control. Note: testicular cord (asterisk) in the medulla (M). IHCDABs, Mayer's haematoxylin counterstained (Figs A, B 200X; C, D 1000X) (Scale bar: 10 mm).

Table I. Quantitation of ER-immunoreactive cells localized in the germinal epithelium of the left male gonad of 8-day-old quail embryo.

\begin{tabular}{lccc}
\hline \multirow{2}{*}{$\begin{array}{l}\text { Number of stage } \\
\text { (P\&I)* embryo (n) }\end{array}$} & \multicolumn{3}{c}{$\begin{array}{c}\text { ER-immunoreactive cells counted in the different } \\
\text { regions of the germinal epithelium }\end{array}$} \\
\cline { 2 - 4 } & Upper & Lateral & Lower \\
\hline 1 & 25 & 19 & 17 \\
2 & 16 & 20 & 17 \\
3 & 22 & 21 & 19 \\
4 & 14 & 14 & 13 \\
5 & 14 & 14 & 15 \\
Total (mean \pm SEM) & $18.20 \pm 1.892$ & $17.60 \pm 1.887$ & $16.20 \pm 1.290$ \\
\hline
\end{tabular}

*= Stage classified according to Padgett \& Ivey (1960) (P\&I). 


\section{DISCUSSION}

Estrogen was reported to play an important role in gonadal differentiation in avian species in both sexes since there have been reported that chicken embryos, particularly in male, treated with exogenous estrogens before gonadal differentiation resulted in sex-reversed embryos (Clinton \& Haines, 2001; Brunström et al., 2003). Estrogen is involved in proliferation of the germinal epithelial cells of male embryonic gonads on day 7-8 of incubation (Romanoff). This study showed that ER could be detected in the germinal epithelial cells, estrogen target cells, of the left male gonad.

Asymmetric expression of ER in male embryonic gonads was noticed since ER is expressed only in the left male gonad but not the right side. The previous study reported that expression of definitive germ cell and pluripotent-associated markers were asymmetric in male chicken embryos (Intarapat \& Stern, 2013). The significance of asymmetric expression of ER and other embryonic stem cell markers in chicken embryos is still unknown. However, the germinal epithelial cells were reported to be estrogen target cells acting via estrogen receptor (Morán, 2005). From our pervious study, we found that in ovo exposure of phytoestrogen to male quail embryo caused thickening of the cortex of the left male gonad (Intarapat et al., 2014). The character of having thick cortex in male quail embryonic gonad after exposure to exogenous estrogens is called "ovotestis" (Perrin et al., 1995; Berg et al., 2001; Oshima et al., 2012). It has been reported that a number of ER in germinal epithelial cells were increased by phytoestrogen (Anderson et al., 1999). This suggests that ER is involved in proliferation of germinal epithelial cells of the embryonic gonads. Mechanism underlying ER-induced feminization and gonadal development in male chicken embryos require further investigation.

Expression of chicken estrogen receptor gene (cER) can be detected in 7.5-day-old embryo in both sexes; moreover, the left gonad had more expression than the right gonad (Andrews et al.; Smith et al., 1997; Nakabayashi et al.). Obviously, cER transcript was found only in the left but not the right side of male embryonic gonad (Andrews et al.). The question why ER expression is restricted in the left male gonad is still unknown. Nevertheless, asymmetric expression of ER in female embryo is associated with gonadal asymmetry in female birds as estrogen induces cortical development leading to the thickening of the cortex in the left female gonad (Nakabayashi et al.; Morán).
ER mRNA was first detected in the germinal epithelium of the left male gonad on day seven of incubation (Nakabayashi et al.). This study found ER protein localized in the nucleus and cytoplasm of the germinal epithelial cells of 8-day-old quail embryo which is classified as phase of gonadal differentiation (Intarapat \& Satayalai). This result indicates that cER gene might encode cER protein to function during such phase. Molecular mechanism by which ER is involved in left-right asymmetry in male embryo require future study.

\section{ACKNOWLEDGEMENTS}

The authors would like to thank Artchariya Chaiyarat for technical assistance.

INTARAPAT, S.; SAILASUTA, A. \& SATAYALAI, O. Localización inmunohistoquímica del receptor de estrógeno en la gónada embrionaria en el embrión de codorniz macho durante la diferenciación gonadal. Int. J. Morphol., 34(2):575-579, 2016.

RESUMEN: En las aves, la gónada embrionaria en los machos se desarrolla bilateralmente, ambos testículos producen espermatozoides funcionales, mientras que en el embrión hembra, sólo la gónada izquierda se convierte en un ovario funcional. El estrógeno juega un papel clave en la determinación del sexo aviar, en ambos sexos, mediante la unión al receptor de estrógeno (RE). Fuertemente los receptores de estrógenos de pollo (cRE) el ARNm se expresan en ambos sexos; además, su expresión sólo se produce en la gónada izquierda del macho. El objetivo fue localizar proteínas del RE en la gónada izquierda de embriones de codorniz macho mediante inmunohistoquímica. Se estudiaron embriones de codorniz machos a los 8 días de edad, cuyo sexo embrionario se distinguió por la morfología de las gónadas. La histología de la gónada izquierda estuvo representada por la corteza delgada que contiene de 1 a 2 capas del epitelio germinal, mientras que se observaron cordones testiculares en la médula. El RE se encontró en células inmunorreactivas del epitelio germinal, pero no en la médula. Se detectó la localización de RE en el núcleo y el citoplasma de las células epiteliales germinales. El número de células REinmunorreactivas en las regiones superior, lateral e inferior del epitelio germinal fue de $18,20 \pm 1,892,17,60 \pm 1,887$ y $16,20 \pm 1,290$, respectivamente. Este estudio muestra la primera evidencia de expresión de la proteína de RE en la gónada izquierda del embrión aviar macho, lo que indica que el RE desempeña un papel en la diferenciación sexual de la gónada aviar.

PALABRAS CLAVE: Receptor de estrógeno; Gónada embrionaria; Diferenciación gonadal; Embrión de codorniz. 


\section{REFERENCES}

Anderson, J. J.; Anthony, M.; Messina, M. \& Garne, S. C. Effects of phyto-oestrogens on tissues. Nutr. Res. Rev., 12(1):75-116, 1999.

Andrews, J. E.; Smith, C. A. \& Sinclair, A. H. Sites of estrogen receptor and aromatase expression in the chicken embryo. Gen. Comp. Endocrinol., 108(2):182-90, 1997.

Berg, C.; Halldin, K. \& Brunström, B. Effects of bisphenol A and tetrabromobisphenol A on sex organ development in quail and chicken embryos. Environ. Toxicol. Chem., 20(12):283640, 2001.

Brunström, B.; Axelsson, J. \& Halldin, K. Effects of endocrine modulators on sex differentiation in birds. Ecotoxicology, 12(1-4):287-95, 2003.

Clinton, M. \& Haines, L. C. An overview of factors influencing sex determination and gonadal development in birds. EXS, (91):97-115, 2001.

Gasc, J. M. Estrogen target cells in gonads of the chicken embryo during sexual differentiation. J. Embryol. Exp. Morphol., 55:331-42, 1980 .

Hamburger, V. \& Hamilton, H. L. A series of normal stages in the development of the chick embryo. 1951. Dev. Dyn.,195(4):231-72, 1992.

Intarapat, S.; Sailasuta, A. \& Satayalai, O. Anatomical and histological changes of reproductive organs in japanese quail (Coturnix japonica) embryos after in ovo exposure to genistein. Int. J. Poult. Sci., 13(1):1-13, 2014.

Intarapat, S. \& Satayalai, O. Microanatomical Study of Embryonic Gonadal Development in Japanese Quail (Coturnix japonica). Anat. Res. Int., 2014:168614, 2014.

Intarapat, S. \& Stern, C. D. Sexually dimorphic and sexindependent left-right asymmetries in chicken embryonic gonads. PLoS One, 8(7):e69893, 2013.

Intarapat, S. \& Stern, C. D. Left-right asymmetry in chicken embryonic gonads. J. Poult. Sci., 51(4):352-8, 2014.

Morán, M. G. Immunohistochemical detection of estrogen receptor alpha in the growing and regressing ovaries of newly hatched chicks. J. Mol. Histol., 36(1-2):147-55, 2005.

Nakabayashi, O.; Kikuchi, H.; Kikuchi, T. \& Mizuno, S. Differential expression of genes for aromatase and estrogen receptor during the gonadal development in chicken embryos. J. Mol. Endocrinol., 20(2):193-202, 1998.
Oshima, A.; Yamashita, R.; Nakamura, K.; Wada, M. \& Shibuya, $\mathrm{K}$. In ovo exposure to nonylphenol and bisphenol A resulted in dose-independent feminization of male gonads in Japanese quail (Coturnix japonica) embryos. Environ. Toxicol. Chem., 31(5):1091-7, 2012.

Padgett, C. S. \& Ivey, W. D. The normal embryology of the Coturnix quail. Anat. Rec., 137:1-11, 1960.

Perrin, F. M.; Stacey, S.; Burgess, A. M. \& Mittwoch, U. A quantitative investigation of gonadal feminization by diethylstilboestrol of genetically male embryos of the quail Coturnix coturnix japonica. J. Reprod. Fertil., 103(2):2236, 1995.

Romanoff, A. L. The Avian Embryo. Structural and Functional Development. New York, Macmillan, 1960.

Smith, C. A.; Andrews, J. E. \& Sinclair, A. H. Gonadal sex differentiation in chicken embryos: expression of estrogen receptor and aromatase genes. J. Steroid. Biochem. Mol. Biol., 60(5-6):295-302, 1997.

Smith, C. A. \& Sinclair, A. H. Sex determination: insights from the chicken. Bioessays, 26(2):120-32, 2004.

\section{Correspondence to: \\ Dr. Sittipon Intarapat \\ Department of Anatomy \\ Faculty of Science, Mahidol University \\ Bangkok, 10400 \\ THAILAND}

Email: sittipon.int@mahidol.ac.th

Received: 16-07-2015

Accepted: 29-02-2016 